\title{
Antioxidant Status of Formulated Drugs Against Typhoid
}

\section{S.S.Haque*}

Department of Clinical Biochemistry, Indira Gandhi Institute of Medical Sciences, Patna, Bihar, India

\begin{abstract}
Background: Typhoid fever (TF) is a global health problem of developing countries which is caused by Salmonella. Salmonella are facultative intra-cellular gram negative bacteria and can survive during certain stages of host parasite interaction. Most of the drugs are resistant now a days that has complicated its management, thus it has necessitated the search of formulated drugs for its treatments. Nitric oxide (NO) is a versatile molecule produced in a biological system. Previous studies have suggested that exogenous administration of L-arginine results in increased NO production, indicating that endogenous substrate is insufficient for maximal NO production. Taking these facts into consideration, it was thought pertinent to see the effect of oral administration of NO donors i.e. L-Arginine along with the low doses of antibiotic (ciprofloxacin).
\end{abstract}

Results and Discussion: On day 11, the treatment of mice with L-arginine, ciprofloxacin and their combination, the GSH level was increased by $20.83 \%, 27.08 \%, 29.10 \%$ and $20.83 \%$ in S.typhimurium infected mice as compared with control, and the GPx activity was significantly increased by $9.92 \%, 4.60 \%, 6.02 \%$ and $3.54 \%$ as compared with control.

Keywords: Typhoid; Nitric oxide; Ciprofloxacin; GSH

\section{Introduction}

Typhoid fever is food borne and water borne infections characteristic of environment with poor sanitations and hygiene [1]. The MDR among Salmonella species has led to fluoroquinolones assuming a primary role in the therapy for invasive salmonellosis. Some investigators have noted increases in the prevalence of S. typhi and $S$. paratyphi strains susceptible to traditional first-line antimicrobials, coinciding with a switch to fluoroquinolones for the management of enteric fever [2,3].These circulating strains of $S$. typhi are highly susceptible to ciprofloxacin [4], a new synthetic fluoroquinolone with a broad spectrum of bactericidal activity and effective tissue penetration [5]. In the treatment of typhoid fever in children ciprofloxacin is successfully used [6], despite controversy over its use in individuals in this age group [7].To obtain better understanding of the pathogenesis of typhoid fever, it seems crucial to elucidate the host defense function of Nitric oxide (NO) against Salmonella. NO is a gaseous, inorganic free radical, and produced in biological system. It regulates a diverse array of physiological functions and acts as inter and extra- cellular messenger in most mammalian organs [8]. Many types of cells, such as leucocytes, hepatocytes, vascular smooth muscle cells and endothelial cells can produce NO during enzymatic conversion of L-arginine to L-citrulline by NO synthetase (NOS). A large amount of NO generated by inducible isoform of the enzyme (iNOS) has been demonstrated. But excess of NO can exert cytotoxic effects [9]. This may involve both i) direct toxicity, e.g., the reaction of $\mathrm{NO}$ with iron-containing enzymes of the respiratory cycle and of the DNA synthetic pathway, and ii) the interaction of $\mathrm{NO}$ with free radicals like superoxide ion (O2- ) to form peroxynitrite (ONOO-), which is a potent oxidizing molecule capable of eliciting lipid peroxidation and cellular damage [10]. In pathological conditions there is an increase in the production of $\mathrm{NO}$ and superoxide anion which ultimately produces perooxynitrite. Consequently, oxidative stress can greatly elevate the production of perooxynitrite[11]. Nitric oxide has been suggested to inhibit the enzymes such as cyclooxygenase, lipooxygenase and cytochrome $\mathrm{P}_{450}$ reduction of active site heme or non-heme iron to inactive ferrous form [12]. NO has been shown to reduce the ferryl heme by which it prevent many oxidative processes [13].

\section{Material and Methods}

\section{Dose and dosage}

Animals: Swiss albino mice (25-30g) 6-8 weeks old were obtained from the central animal house of Hamdard University, New Delhi, India. The animals were kept in Poly-propylene cages in an airconditioned room at $22^{\circ} / 25^{\circ} \mathrm{C}$ and maintained on a standard laboratory feed (Amrut Laboratory, rat and mice feed, Navmaharashtra Chakan Oil Mills Ltd, Pune) and water ad libitum. Animals were allowed to acclimatize for one week before the experiments under controlled light/dark cycle (14/10h). The studies were conducted according to ethical guidelines of the "Committee for the purpose of control and supervision of Experiments on Animals (CPCSEA)" on the use of animals for scientific research.

Bacteria: In this experiment only Salmonella typhimurium (wild) was used. The standard strain of this pathogen was obtained from the National Salmonella Phage Typing Centre, Lady Harding Medical College, New Delhi, India. This bacterial strain was further confirmed by the Department of Microbiology, Majeedia Hospital, New Delhi, India. Animals were divided into six groups. Each group comprised of six animals. The study comprised of treatment schedules (Table 1).

Effects of above drugs on infected mice by $S$. typhimurium were analyzed. Post-treatment of drugs were done at above dose orally to the experimental animals, first group was considered as control that receive only saline, second group considered as positive control which was challenged with sub lethal dose of $S$. typhimurium $\left(0.6 \mathrm{LD}_{50}\right)$

${ }^{*}$ Corresponding author: S.S. Haque, Department of Clinical Biochemistry, Indira Gandhi Institute of Medical Sciences, Patna, Bihar, India, E-mail:sshaq2002@ yahoo.co.in

Received May 23, 2011; Accepted November 28, 2011; Published December 02, 2011

Citation: Haque SS (2011) Antioxidant Status of Formulated Drugs Against Typhoid. Biochem \& Anal Biochem 1:102. doi:10.4172/2161-1009.1000102

Copyright: (c) 2011 Haque SS. This is an open-access article distributed under the terms of the Creative Commons Attribution License, which permits unrestricted use, distribution, and reproduction in any medium, provided the original author and source are credited. 


\begin{tabular}{|c|c|}
\hline Groups & Treatments \\
\hline Group1. & Negative control (Normal Saline) \\
\hline Group2. & Positive control (S. typhimurium $\left(0.6 \times \mathrm{LD}_{50}\right)+$ Saline \\
\hline Group3. & S. typhimurium $\left(0.6 \mathrm{xLD}_{50}\right)+$ Ciprofloxacin (400mgper kg b. wt) \\
\hline Group4. & S. typhimurium $\left(0.6 \mathrm{xLD}_{50}\right)+$ Arginine (1000mg per kg b.wt) \\
\hline Group5. & $\begin{array}{l}\text { S. typhimurium }\left(0.6 \mathrm{xL}_{50}\right)+\text { Arginine }(500 \mathrm{mg} \text { per } \mathrm{kg} \mathrm{b} \text {. wt) +Cipro- } \\
\text { floxacin }(200 \mathrm{mg} \text { per } \mathrm{kg} \mathrm{b} \text {. wt) }\end{array}$ \\
\hline Group6. & $\begin{array}{l}\text { S. typhimurium }\left(0.6 \mathrm{xLD}_{50}\right)+\text { Arginine }(250 \mathrm{mgper} \mathrm{kg} \mathrm{b} \text { bt })+\text { Cipro- } \\
\text { floxacin }(200 \mathrm{mg} \text { per } \mathrm{kg} \text { b. wt) }\end{array}$ \\
\hline
\end{tabular}

Table 1: Treatment Schedule

along with saline. Third group was challenged with sub lethal dose of $S$. typhimurium and given only full dose of ciprofloxacin. Fourth group was challenged with sub lethal dose of S. typhimurium and then mice were treated with full dose of Arginine only. In fifth and sixth group animals were challenged with S.typhimurium and then half and one fourth dose of Arginine was administered along with half dose of Ciprofloxacin respectively. On 11th days of post treatment, liver was removed aseptically in sterile condition, homogenate was made and post mitochondrial supernatant was prepared for biochemical estimation.

\section{Results}

\section{Reduced glutathione (GSH)}

To analyze the effect of L-arginine, ciprofloxacin and their combination on liver damage, hepatic GSH levels in mice were measured. The mice were challenged with sub lethal dose $\left(0.6 \mathrm{LD}_{50}\right)$ of $S$. typhimurium and then treated with drugs. The results have been summarized in Figures1.Infection with bacteria to control mice resulted in significant decrease in the GSH level by $4 \%$ at day 11 . On day 11 , the treatment of mice with $\mathrm{L}$-arginine, ciprofloxacin and their combination, the GSH level was slightly increased by $20.83 \%, 27.08 \%$, $29.1 \%$ and $20.83 \%$ in S. typhimurium infected mice as compared with control.

Glutathione peroxidase (GPx) activity: The main function of glutathione peroxidase $(\mathrm{GPx})$ is to protect the body from oxidative damage. It reduces lipid hydroperoxides to their corresponding alcohols and also reduces free hydrogen peroxide to water. They are the major enzymes that remove hydrogen peroxide generated by SOD in cytosol and mitochondria by oxidizing the tripeptide glutathione (GSH) into its oxidized form (GSSG).

To assess the effect L-arginine, ciprofloxacin and their combination, on liver function. The mice were challenged with sublethal dose $\left(0.6_{\mathrm{x}} \mathrm{LD}_{50}\right)$ of S. typhimurium, and then treated with above drugs. GPx activity was assessed and the results have been summarized in Figures 2. Infection of mice with bacteria resulted in decrease in the GPx activity by $6.62 \%$ at day 11 as compared to saline treated control.

On day 11, the treatment of mice with above drugs, the GPx activity was slightly increased by $9.92 \%, 4.60 \%, 6.02 \%$ and $3.54 \%$ as compared with control.

\section{Discussion}

\section{Reduced glutathione (GSH)}

Reduced glutathione (GSH) plays an important role in the detoxification of reactive toxic metabolites of $\mathrm{S}$. typhimurium; liver necrosis is initiated when reserves of GSH are markedly depleted
$[14,15]$. It was suggested that lowered GSH levels may occur due to increased utilization of GSH by antioxidant enzymes [16]. The reduced form of GSH becomes readily oxidized to GSSG on interacting with free radicals. GSH participates in the reductive processes that are essential for the protection of cells through quenching the reactive intermediates and the radicals generated during oxidative toxicity.

Administration of S. typhimurium to control mice resulted in reduce levels of GSH. Interestingly, our results showed that L-arg and ciprofloxacin both were able to enhance GSH levels in infected $(\mathrm{B}+\mathrm{A} \& \mathrm{~B}+\mathrm{C})$ mice (Figure 1). The maximum increase was found in Ciproflaxacin treated mice at each day 11 of experiment. These increases in GSH level up regulate NO formation. Infected mice showed decrease in GSH level, but increase in NO production. The cost for depletion of GSH might be due to the injury mediated by peroxynitrite in host tissues. Peroxynitrite can oxidize GSH to GSSG, which suggests that this reaction could affect the redox status of intracellular and extracellular thiols [17]. Thus, in bacterial infected group, the peroxynitrite may deplete GSH by converting it to GSSG. This GSSG may not be recycled back to GSH because there is depletion of glutathione dependent enzymes. The iNOS inhibitor group (IB) showed depletion in GSH level and $\mathrm{NO}$ production.

S-nitrosothiols such as S- nitrosoglutathione (GSNO) can be formed from $\mathrm{NO}$ and reduced thiols (reduced glutahione) in presence of an electron acceptor [18]. S-nitrosoglutathione can be bacteriostatic [19] and bacteriocidal [20,21,22] Studies with the Gramnegative bacterium $S$. typhimurium indicate that S-nitrosoglutathione appears to be recognized as a substrate by the periplasmic enzyme $\gamma$-glutamyltranspeptidase, with subsequent conversion to S-nitrosocysteinyl-glycine. This nitrosylated dipeptide in turn is imported into bacterial cytoplasm across the inner membrane by a specialized dipeptide permease (DPP). The presence of dipeptide permease, a member of the ABC (ATP-binding cassette) transporter family, is absolutely essential for GSNO mediated inhibition of S. typhimrium growth in vitro. The ability of GSNO to halt the replication of S. typhimurium is markedly reduced by a mutation in DPP, which encodes the dipeptide permease [19].

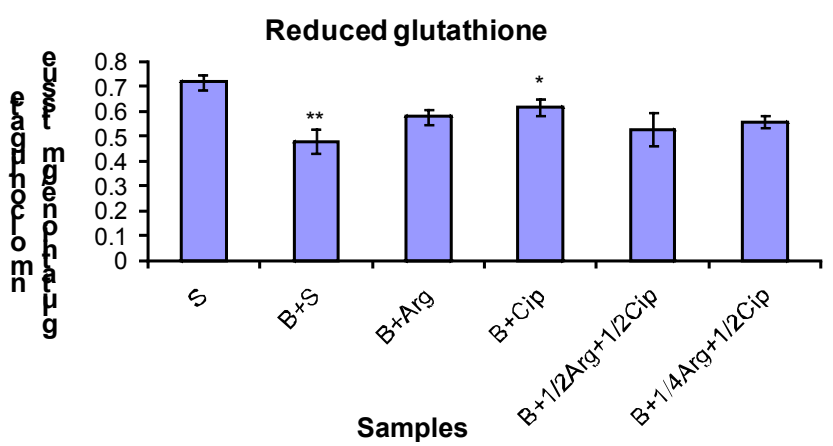

Figure 1: Hepatic reduced glutathione levels in mice: drugs were given and study was made on day 11 with arginine, ciprofloxacin and their combination. $S=S a l i n e$, $\mathrm{B}+\mathrm{S}=\mathrm{S}$. typhimurium+Saline, $\mathrm{B}+\mathrm{Arg}=\mathrm{S}$. typhimurium $+1000 \mathrm{mg}$ per $\mathrm{kg} \mathrm{b}$. wt $\mathrm{L}-$ Arginine, $\mathrm{B}+\mathrm{Cip}=\mathrm{S}$. typhimurium $+400 \mathrm{mg}$ per $\mathrm{kg} \mathrm{b}$. wt Ciprofloxacin, B+1/2Arg $+1 / 2 \mathrm{Cip}=S$. typhimurium $+500 \mathrm{mg}$ per $\mathrm{kg} \mathrm{b}$. wt Arginine+200 mg per $\mathrm{kg}$ b. wt ciprofloxacin, $\mathrm{B}+1 / 4 \mathrm{Arg}+1 / 2 \mathrm{Cip}=S$. typhimurium $+250 \mathrm{mg}$ per $\mathrm{kg}$ b. wt Arginine+200mg per kg b. wt Ciprofloxacin.

Values are significantly different ${ }^{*} p<0.05$ and ${ }^{* *} p<0.01$ 


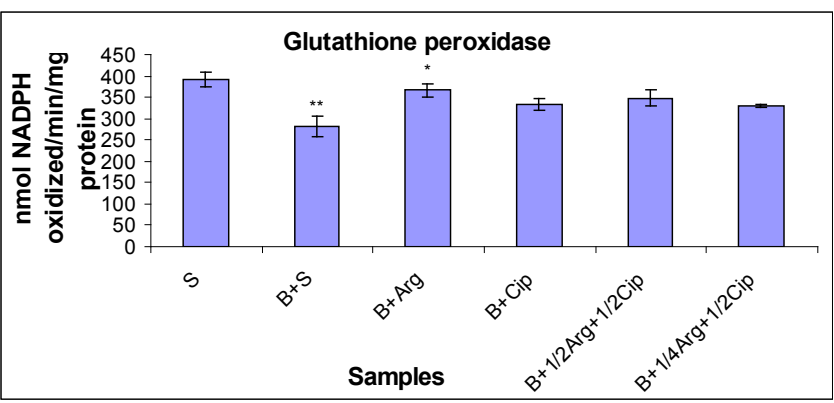

Figure 2: Hepatic GPx activity in mice: drugs were given and study was made on day 11 with arginine, ciprofloxacin and their combination. $S=S a l i n e, B+S=S$. typhimurium+Saline, $\mathrm{B}+\mathrm{Arg}=S$. typhimurium $+1000 \mathrm{mg}$ per $\mathrm{kg} \mathrm{b}$. wt L-Arginine, $\mathrm{B}+\mathrm{Cip}=\mathrm{S}$. typhimurium+400mg per $\mathrm{kg}$ b. wt Ciprofloxacin, $\mathrm{B}+1 / 2 \mathrm{Arg}+1 / 2 \mathrm{Cip}=S$ typhimurium+500mg per $\mathrm{kg} \mathrm{b}$. wt Arginine+200 mg per $\mathrm{kg}$ b. wt ciprofloxacin $\mathrm{B}+1 / 4 \mathrm{Arg}+1 / 2 \mathrm{Cip}=S$. typhimurium+250mg per $\mathrm{kg} \mathrm{b}$. wt Arginine+200mg per kg b. wt Ciprofloxacin.

Values are significantly different ${ }^{*} p<0.05$ and ${ }^{* *} p<0.01$

\section{Glutathione peroxidase}

Similarly, our results suggest that enhanced GPx activity was found in liver in combination $(\mathrm{B}+1 / 2 \mathrm{Arg}+1 / 2 \mathrm{Cip})$ of drugs at day 11 maximum increase was seen in L-Arg and combination of drugs $(\mathrm{B}+1 / 2$ Arg+1/2 Cip) (Figures 2). These results are consistent with report of Farias-Eisner et al, (1996). In contrast to our study Asahi et al, (1995), on the other hand reported that GPx could be inhibited by putative NO donor S-nitro-N-acetyl pencillianine (SNAP) in U937 cells. Gluthathione peroxidase can catabolize peroxynitrite in vitro [23] and many small biological molecules including glutathione, cysteine, methionine and tyrosine can react with peroxynitrite or its toxic products [24] reported a new function for selenoproteins as peroxynitrite reductase. It increased the formation of nitrite from peroxynitrite and was able to defend human fibroblast cells against peroxynitrite mediated oxidation. Peroxynitrite is known to inactivate GPx by the oxidation of essential thiol or selenol [25]. Similar trends were observed in case of glutathione reductase activity (Figure 2).

\section{References}

1. Singh A, Mcfeters G (1992) Detection methods of water borne pathogens, in: Mitchell R (Ed) Environmental Microbiology, Wiley-liss, New York 125-189.

2. Rowe B, Ward LR, Threlfall EJ (1997) Multidrug-resistant Salmonella typhi: a worldwide epidemic. Clin Infect Dis 24: 106-109.

3. Gupta SK, Medalla F, Omondi MW (2008) Laboratory-based surveillance of paratyphoid fever in the United States: travel and antimicrobial resistance. Clin Infect Dis 46: 1656-1663.

4. Saha MR, Dutta P, Bhattacharya SK, Rasaily R, Mitra U, et al. (1992) Occurrence of multi-drug resistant Salmonella typhi in Calcutta. Indian J Med Res 95: 179-180.

5. Drug Therapy Bulletin (1987) Ciprofloxacin-an important new antimicrobial Drug Ther Bull 25: 69-72.

6. Sen S, Goyal RS, Dev R (1991) Ciprofloxacin in the management of multidrug resistant typhoid fever. Indian Pediatr 28: 417-419.

7. Adam D (1989) Use of quinolones in pediatric patients. Rev Infect Dis 2: 11131116.

8. Misko TP, Schilling RJ, Salvemini D, Moore W, Currie MG (1993) A fluorometric assay for the measurement of nitrite in biological samples. Anal Biochem 214: $11-16$.

9. Stefenovic-Racic M, Stadler J, Evans CH (1993) Nitric oxide and arthritis. Arthritis Rheum 36: 1036-1044.

10. Michael T, Feron O (1997) Nitric oxide synthesis: Which, where, how and why? $\mathrm{J}$ Clin Invest 100: 2146-2152.
11. Utley HC, Bernheim F, Hachstein P (1967) Effect of sulfhydryl reagent on peroxidation in microsome. Arch Biochem Biophys 260: 521-531.

12. Rastaldo R, Pagliaro P, Cappello S, Penna C, Mancardi D, et al. (2007) Nitric oxide and cardiac function. Life Sciences 81: 779-793.

13. Jollow DJ, Mitchell JR, Zampaglione M, Gillete JR (1974) Bromobenzene induced liver necrosis: Protective role of glutathione and evidence for 3 , 4-bromobenzene as the hepatotoxic intermediate. Pharmacol 11: 151-169.

14. Mohandas J, Marshall JJ, Duggin GG, Horvath JS, Tiller D (1984) Differential distribution of glutathione related enzymes in rabbit kidney: possible implications in analgesic neuropathy. Cancer Res 44: 5086-5091.

15. Recknagel RO, Glende EA, Dolak JA, Waller RL (1989) Mechanisms of carbon tetrachloride toxicity. Pharmacology and Therapeutics. 43: 139-154.

16. Williams AT, Burk RF (1990) Carbon tetrachloride hepatotoxicity: an example of free radical-mediated injury. Semin Liver Dis 10: 279-284.

17. Anand L, Brajachand NG, Dhanachand CH (1996) Cryptosporidiosis in HIV infection. J Commun Dis 28: 241-244.

18. Wink DA, Cook JA, Kim SY, Vodovotz Y, Pacelli R, et al. (1997) Superoxide moduletes the oxidations and nitrosation of thiols by nitric oxide-derived reactive intermediates: chemical aspects involved in the balances between oxidations and nitrosative stress. J Biol Chem 272: 11147-11151.

19. Gow AJ, Thom SR, Brass C, Ischiropoulos H (1997) Electro-chemical detection of nitric oxide in biological systems. Microchem J 56: 146-154.

20. De Groote MA, Granger D, Xu Y, Campbell G, Prince R et al. (1995) Genetic and redox determinants of nitric oxide cytotoxicity in a Salmonella typhimurium model. Proc Natl Acad Sci USA 92: 6399-6403.

21. Shiloh M, Ruan J, Nathan C (1997) Evaluation of bacterial survival and phagocyte function with fluorescence-based microplate assay. Infect Immun 65: 3193-3197.

22. Chen X, Cao J, Xu Q (2000) Endotoxin exacerbates immunologically induced liver injury in cooperation with interferon-gamma. Inflamm Res 49: 571-577.

23. Miyamoto $Y$, Akaike T, Alam MS, Inoue $K$, Hamamoto $T$, et al. (2000) Nove functions of human alpha(1)-protease inhibitor after S-nitrosylation: inhibition of cysteine protease and antibacterial activity. Biochem Biophys Res Commun 267: 918-923.

24. Briviba K, Kissner R, Konnenol WH, Sies H (1998) Kinetic study of the reaction of glutathione peroxide with peroxynitrite. Chem Res Toxicol 11: 1398-1401.

25. Sies H, Sharov V, Klotz LO, Briviba K (1997) Glutathione peroxidase protects against peroxynitrite-mediated oxidations. A new function for selenoproteins as peroxynitrite reductase. J Biol Chem 272: 27812-27817.

26. Asahi M, Fujji J, Takao T, Kuzuya T, Hori M, et al. (1997) The oxidation of selenocysteine is involved in the inactivation of glutathione peroxidase by nitric oxide donor. J Biol Chem 272: 19152-19157. 